\title{
The Relationship among the Structural, Cellular, and Physical Properties of Walnut Shells
}

\author{
Shugang Zhao' ${ }^{1}$, Jiamin Niu, and Linying Yun ${ }^{1}$ \\ College of Life Sciences, Hebei Agricultural University, Baoding, 071001, \\ Hebei, P.R. China
}

Kai Liu, Shuang Wang, and Jing Wen
Mountainous Areas Research Institute, Hebei Agricultural University,
Baoding, 071001, Hebei, P.R. China

Hongxia Wang ${ }^{2}$ and ZhiHua Zhang ${ }^{2}$

Mountainous Areas Research Institute, Hebei Agricultural University, Baoding, 071001, Hebei, P.R. China; Research Center for Agricultural Engineering Technology of Mountain District, Baoding, 071001, Hebei, P.R. China; and National Engineering Reaearch Center for Agriculture in Northern Mountainous Areas, Hebei Agricultural University, Baoding, 071001, Hebei, P.R. China

Additional index words. Juglans regia, sclereids, lignin, cellulose, sclereids, component

\begin{abstract}
The role of the walnut (Juglans regia L.) shell in nut development, transportation, cleaning, and storage is often ignored. The shell suture seal and thickness are directly associated with kernel characteristics. In the present study, shell differentiation and microstructure were observed with an optical microscope using paraffin-sectioning and cryosectioning. The results showed that the parenchymal cells of the endocarp began to differentiate into sclerenchymal cells from $49 \mathrm{~d}$ after flowering (DAF), and the entire process continued until fruit maturation. The mature shell consists of three parts, including the sclereid layer (L1), sclerenchymal cell layer (L2), and shrunken cell layer (L3), from the outside to the inside. The shell thickness, suture seal grade, and mechanical strength were evaluated, as well as the lignin, cellulose, and phenolic compounds of the shell. Suture seal grade was positively correlated with lignin content, shell thickness, and L1 thickness and negatively correlated with shell cell diameter. Similarly, the mechanical strength of the shell was positively correlated with lignin content and L1 thickness. 'Qingxing' fruits were subjected to two treatments, namely, $30 \%$ shading and $70 \%$ shading, from $10 \mathrm{~d}$ after anthesis to maturity, with no shading used as control. After harvesting in September, nutshell sections showed thinner shells, with decreased contents of lignin and polyphenols, obtained under shaded conditions, and two of the three parts of the shell changed dramatically. The thinning of $L 1$ and thickening of L3 eventually led to a thinner shell. The aim of this study was to evaluate the relationship among the shell structure, cellular components, and physical properties and provide a theoretical basis for cultivar breeding, rational planting density, and regulation of shell development.
\end{abstract}

Walnut (Juglans regia L.) is an important crop that is cultivated extensively worldwide for nut production. China is one of the major producers of this crop. Traditional Chinese medicine purports that the nutmeat of walnut is nutrient-dense and beneficial for brain health. Similarly, many tissues of the walnut besides the nut, including the husk, shell,

Received for publication 17 July 2018. Accepted for publication 18 Sept. 2018.

This work was supported by the National Science Foundation Special Project (2013FY111700-5). We thank LetPub (www.letpub.com) for providing linguistic assistance during the preparation of this article.

${ }^{1}$ These authors contributed equally to this work. ${ }^{2}$ Corresponding authors. E-mail: whx@hebau.edu. cn or zzh@hebau.edu.cn.
Under the epidermis, there are multilayer parenchymal cells containing chloroplasts and phenols in vesicles, which are rich in phenolic compounds. 2) Subsequently, the boundaries between the exocarp, mesocarp, and endocarp become clearer, along with the emergence of two layers of sclereids under the epidermis. The volume of parenchymal cells in the mesocarp increases rapidly (by a dozen or dozen-fold). 3) Finally, 4 to 5 vascular bundles develop in the exocarp, and the endocarp transforms into a hard shell composed of lignified sclereids. The pattern of shell-hardening is basipetal in the longitudinal plane and centripetal in the transverse plane. The first cells to become sclerified are those at the micropylar end (the upper part of the fruit), with sclerification occurring in early June (Pinney and Polito, 1983; Zhao et al., 2016). Sclerification proceeds basipetally from this point, with the cells along the seal lines becoming sclerified rapidly. Completion of sclerification from this point occurs in less than a week. Only the outermost one-half to two-thirds of this tissue actually contributes to the shell, and the remainder contributes to the packing tissue (Pinney and Polito, 1983).

With grafting and budding being extensively applied in commercial nurseries over the past few decades, new thin-shelled cultivars have been propagated and planted across China. Most of these cultivars are derived from precocious Xinjiang walnuts (lateralfruiting type) (Pei and Lu, 2011; Xi, 1990) and are accustomed to a Mediterranean climate, which is associated with high light, dry air, and low planting density. However, the climate of central and eastern China is hot and humid in summer. Due to various factors, such as the selected walnut cultivars, climatic conditions, high planting density, extensive cultivation, and poor management, the ratios of dehiscent nuts, incomplete hulls, and dark kernels have rapidly increased after harvest, which has influenced the quality of the kernel in recent years. Additionally, recent studies have shown that shell thickness is significantly positively correlated with nut weight, which itself is significantly negatively correlated with kernel percentage (Arzani et al., 2008; Zhao et al., 2007). Shell thickness was one of the main variables accounting for kernel percentage and should be considered in breeding (Amiri et al., 2010). In addition, shell structural features such as shape, thickness, and texture, were the most important parameters affecting kernel extraction quality in nuts (Amiri et al., 2014; Ghafari et al., 2011). Many walnut-producing countries use relevant walnut shell features in breeding objectives (Avanzato et al., 2014).

Here, shell differentiation and microstructure were analyzed using paraffin sections and cryosections, and the relationship among the structure, components, and physical properties were illuminated. The aim of this study was to ascertain the influence of shell structure and components on the physical properties of the walnut and provide a theoretical basis for cultivar breeding, rational planting density, and regulation of shell development. 


\section{Material and Methods}

Plant materials. Walnut fruit from nine cultivars was used, including Zanmei (ZM), Qingxiang (QX), Liaohe 1 (LH1), Liaohe 2 (LH2), Zhonglin 5 (ZL5), Qingcui (QC), Fenghui (FH), Lvbo (LB), and Shangsong 6 (SS6), all of which are cultivated in China. Fresh fruit was collected at the Dingzhou Desheng Agriculture and Forestry Science and Technology Co. Ltd., an orchard in Hebei province. The orchard has a planting density of $6 \mathrm{~m} \times 8 \mathrm{~m}$, and all the trees are more than 9 years old. They are pruned when necessary and receive standard fertilization. The silty loam soil is tilled and irrigated in spring (March and May). Fresh samples of ZM, including 10 fruits, were collected at an interval of $6 \mathrm{~d}$ from full bloom to harvesting. Fruits of each period were randomly collected from four directions on the tree (east, south, west, and north). At harvest season, the nuts of all cultivars were collected after fruit ripening, using 30 nuts of each cultivar.

From $10 \mathrm{~d}$ after anthesis to maturity, shading nets with different light transmittance rates were used to shade the young fruit from sunshine. Two treatments were carried out, including 30\% shading (38000 1x) and 70\% shading $(16500 \mathrm{~lx})$, with no shading $(55000$ $1 \mathrm{x})$ used as the control. Three replicates were included in this experiment. The walnuts were harvested at the mature stage and used to study the effect of light on the shell.

Specimen preparation for light microscopy. The fruit (endocarp) was cut into $\approx 5 \mathrm{~mm}^{3}$ cubes and fixed in $2.5 \%(\mathrm{v} / \mathrm{v})$ glutaraldehyde and 3\% (v/v) polyformaldehyde in phosphatebuffered saline (PBS) buffer [4 mM sodium phosphate, $\mathrm{pH} 7.2 ; 200 \mathrm{~mm}$ sodium chloride $(\mathrm{NaCl})$. After extensive washing in PBS buffer, the tissues were then processed as follows: sequentially dehydrated at ambient temperature in $70 \%, 85 \%, 95 \%$, and $100 \%$ ethanol ( $1 \mathrm{~h}$ for each step); vitrified with a gradient from $100 \%$ ethanol to $100 \%$ xylene; and infiltrated and embedded in paraffin. Sections of $8 \mu \mathrm{m}$ were then made using a microtome (KEDEE KD225) and subsequently mounted on adhesive microscopic slides and stained with $1 \%$ safranin and $0.5 \%$ fast green and then covered with a coverslip ( $0.17 \mathrm{~mm}$ thickness). Cryosection was used on the hard shell tissue. The mature fruit shell samples were infiltrated in $10 \%(\mathrm{v} / \mathrm{v})$ glycerol for 30 min by maintaining a partial vacuum and then incubated for $4 \mathrm{~h}$ at room temperature. After infusion, the tissue segments were placed on a specimen holder (UDE SYD-K2040) and covered with the same concentration of glycerol infusion to maintain them in a form suitable for sectioning. Sections were examined with an Olympus (Tokyo, Japan) microscope (BH-2).

Lignin deposition and determination. The fruit was longitudinally cut into halves for the Wiesner test (Lin et al., 2002). Each part was treated with $2 \%$ phloroglucinol in a $95 \%$ ethanol solution for $5 \mathrm{~min}$ and mounted in $6 \mathrm{M} \mathrm{HCl}$ to examine if the cinnamaldehyde groups of the lignin were present before the coverslips were applied.

Lignin determination was carried out as described by Tao et al., (2009), with some modifications. The shell was ground into a powder and then sieved through a 120 -mesh sieve. The powder was then washed with $95 \%$ ethanol, after which the sediment was washed with $95 \%$ ethanol and ethanol:hexane $(1: 2, \mathrm{v} / \mathrm{v})$ three times, respectively, and dried. The dried sediment was digested in $5 \mathrm{~mL}$ of $25 \%(\mathrm{v} / \mathrm{v})$ acetyl bromide in acetic acid and $0.2 \mathrm{~mL}$ of perchloric acid, incubated for $30 \mathrm{~min}$ at $70{ }^{\circ} \mathrm{C}$ and oscillated every $10 \mathrm{~min}$. The reaction was ended by the addition of 0.9 $\mathrm{mL}$ of $2 \mathrm{~N} \mathrm{NaOH}$ with an extra $5 \mathrm{~mL}$ of acetic acid and $0.1 \mathrm{~mL}$ of $7.5 \mathrm{M}$ hydroxylamine hydrochloride. The volume was corrected to $10 \mathrm{~mL}$ with acetic acid and the absorbance at A280 was measured. The amount of lignin was calculated from a linear calibration curve using commercial alkali lignin. Three replicates were included in this experiment. At least 15 samples were used in each replicate.

Measurement of cellulose content. The lyophilized shell samples were used in the determination of cellulose content. After being ground, the shell powder was sieved through a 120-mesh sieve and subjected to acetic acid/nitric acid digestion and incubated $100{ }^{\circ} \mathrm{C}$ for $30 \mathrm{~min}$. The solution was then cooled at room temperature (Updegraff, 1969), centrifuged at $4000 g_{n}$ for $15 \mathrm{~min}$, and the supernatant discarded. The dried sediment was resuspended in $72 \%$ sulfuric acid, and the cellulose content was quantified using an anthrone assay (Abidi et al., 2014). Three replicates were included in this experiment. At least 15 samples were used in each replicate.

Extraction of phenolic compounds. The total phenolic content was determined using the Folin-Ciocalteu colorimetric method (Zhao et al., 2016). Briefly, each sample $(0.1 \mathrm{~g})$ was thoroughly mixed with $5 \mathrm{~mL}$ of Folin-Ciocalteu reagent (diluted 10-fold), followed by the addition of $8 \mathrm{~mL}$ sodium carbonate $(10 \%)$ solution. After incubation at $30{ }^{\circ} \mathrm{C}$ for $120 \mathrm{~min}$, the absorbance was measured at $765 \mathrm{~nm}$ using an ultraviolet spectrophotometer (Shimadzu Corp., Kyoto, Japan). Gallic acid was used as a standard and the results were expressed in milligrams gallic acid equivalents per gram fresh weight (FW). Three replicates were included in this experiment. At least 15 samples were used in each replicate.

Shell thickness, suture seal grade, and mechanical strength determination. The shell thickness sample was obtained from the middle position of the nut and measured using a vernier micrometer. Suture seal grade and mechanical strength determination were carried out as described by Zhao et al. (2007). Three replicates were included in this experiment. At least 10 samples were used in each replicate.

Statistics. The experiment was arranged in a completely randomized design. The contents of investigated phenolic compounds were expressed in milligrams per gram FW as mean values with standard deviations. Differences in content levels among the cultivars were estimated using Duncan's new multiple range test. Data were also subjected to Pearson correlation analysis. The standard deviations and correlation scores were calculated to compare any significant treatment effects at the $5 \%$ level using SPSS version 20.0 (IBM Corp., Armonk, NY) and Excel 2010 software (Microsoft Corp., Albuquerque, NM).

\section{Results}

Endocarp development. The fruit of the walnut is a type of accessory fruit known as a pseudo drupe (Xiao et al., 1998), and the outer covering of the fruit is an involucre. The husk is developed from the involucre, and the shell is developed from the carpel. At $7 \mathrm{DAF}$, the boundary of the three layers (the pericarp, mesocarp, and endocarp) could not be distinguished clearly, except for a few layers of red cells between the stained mesocarp and endocarp (Fig. 1A). Nevertheless, the cells inside the endocarp were relatively small and closely arranged and differed significantly from the outer cells (Fig. 1A-1). After 2 weeks (21 DAF), the husk and endocarp gradually appeared, and parenchymal cells grew and expanded in the husk, in which increasing numbers of vascular bundles were scattered (Fig. 1B). At this time, oblong-shaped parenchymal cells that were suitably arranged at the boundary of the mesocarp and endocarp could be distinguished clearly, differing from the adjacent cells (Fig. 1B-2).

From 35 DAF to 42 DAF, the cells of the endocarp continued to divide and increase, while the parenchymal cells between the endocarp and husk were flat, elongated, and in a horizontal direction (Fig. 1C and D). At $42 \mathrm{DAF}$, the fruit was cut longitudinally, and the milky white immature shell and pericarp could be clearly distinguished. The Wiesner reaction showed that there was no deposition of lignin in the pericarp during this period (Fig. 2A).

From 49 DAF to 112 DAF, the endocarp cells, which had previously rapidly divided, became lignified and increased moderately in size, and the fruit size tended to stabilize. At 49 DAF, lignification started from the apical tip of the endocarp (Fig. 2B), and a large number of parenchymal cells adjacent to the husk began to thicken the secondary wall (Fig. 1E). Subsequently, the endocarp lignified gradually from the apical tip to the base. The cells between the endocarp and the epidermis continued to flatten (Fig. 1E-5). At 56 DPA, the lignified parts of the endocarp gradually increased (Fig. 2C). At 63 DAF (June 15), all of the cells in the periphery of the endocarp had lignified (Figs. 1F and 2D), in which secondary cell walls appeared and filled the lumen gradually. The parenchymal cells between the endocarp and husk decreased to just two to four layers and became slender (Fig. 1F-6). Thereafter, the shell lignified greatly and became extremely hard. At $70 \mathrm{DAF}$, the Wiesner reaction indicated that the endocarp had rapidly lignified from the outside to the inside (Fig. 2E). The secondary wall of the sclereids continued to thicken, and the lumen became smaller (Fig. 1G). The husk and the parenchymal cells between the inner pericarp had become gradually linear (Fig. 1G-7). From 84 DAF (July 23) to 112 DAF (Aug. 8), the thickness of the lignified part of the endocarp did not 

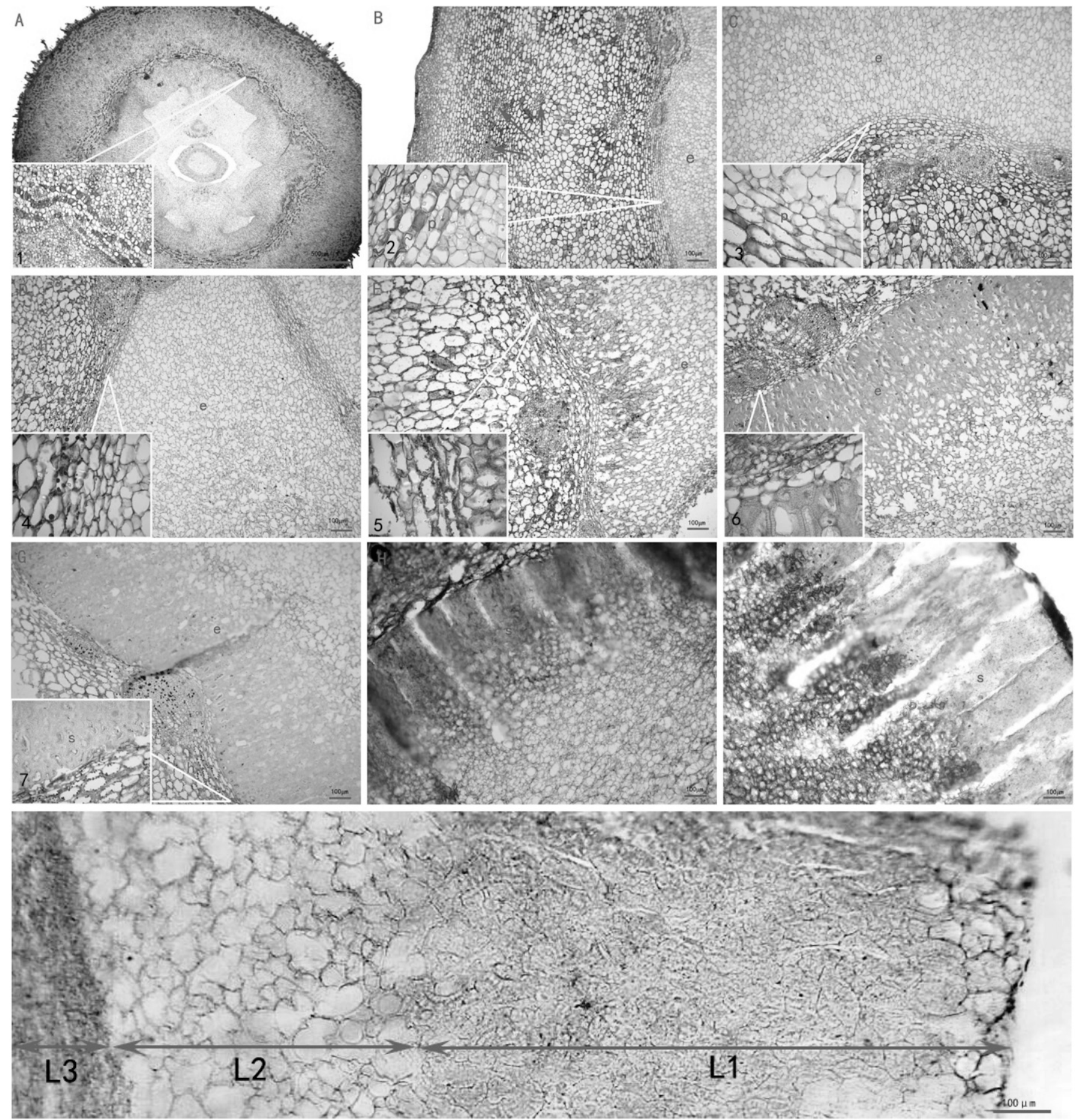

Fig. 1. Development process of the walnut pericarp. The boundary of the pericarp, mesocarp, and endocarp could not be distinguished clearly at $7 \mathrm{~d}$ after flowering (DAF) (A and 1). The mesocarp and endocarp could be distinguished clearly at $21 \mathrm{DAF}(\mathbf{B})$. The endocarp cells continued to divide and increase from 35 to 42 DAF $(\mathbf{C}$ and $\mathbf{D})$. The endocarp cells underwent lignification and moderately increased in size $(\mathbf{E}-\mathbf{I})$. The endocarp consisted of three parts from the outside in L1, L2, and L3 (J). The development of parenchymal cells between the husk and endocarp $(1-6) . \mathrm{h}=$ husk; $\mathrm{e}=$ endocarp; $\mathrm{v}=$ vascular bundle; $\mathrm{s}=\mathrm{sclereids;} \mathrm{p}=$ parenchymal cell; L1 = sclereids layer; L2 = sclerenchymal cells layer; L3 = shrunken cell layer.

change much (Fig. 2F-H), and the secondary walls of the endocarp sclereids continued to thicken (Fig. 1H and I).

From 112 DAF (Aug. 8) to maturity, significant increases in lignin deposition occurred in the endocarp (Fig. 2I), and the parenchymal cells at the inner side of the endocarp gradually shrank. At the end of fruit maturation, the endocarp formed the nut shell, which consisted of three parts from the outside in: a layer of sclereids with an extremely thick secondary cell wall (L1), a layer of sclerenchymal cells with a partly thickened secondary cell wall (L2), and a layer of shrunken cells without a secondary cell wall (L3) (Fig. 1J).

Shell structure and physical properties. Following harvesting of the mature walnut, different cultivars were collected and hulled. The shell thickness of the cultivars ranged from 0.66 to $1.21 \mathrm{~mm}$. The shell thickness of $\mathrm{ZM}$ was greatest $(1.21 \mathrm{~mm})$ and that of $\mathrm{LH} 2$ was the lowest $(0.66 \mathrm{~mm})$, and differed significantly from the other cultivars. The suture seal grade measurement system was then used to determine the mechanical strength and suture seal force. Mechanical strength is represented by shell hardness, and the suture seal force reflected the tightness of the two carpels (shells). The mechanical 


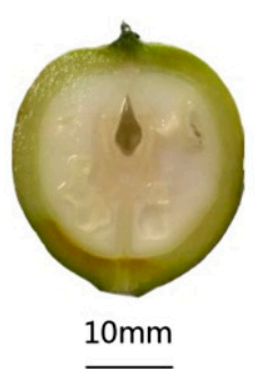

A

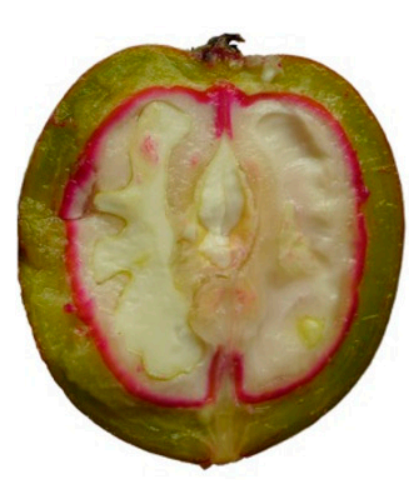

$\mathrm{F}$

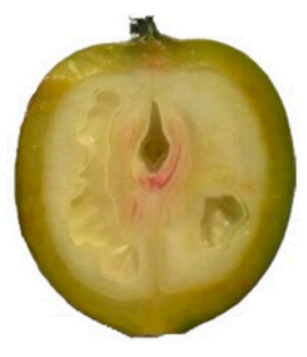

B

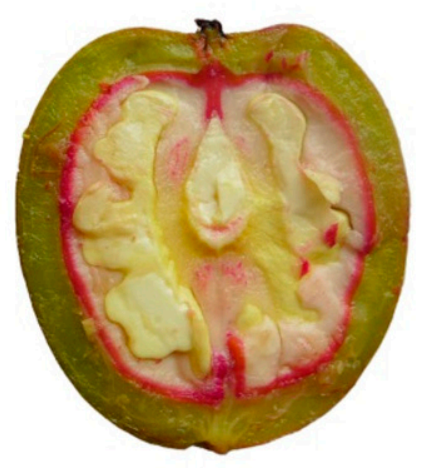

G

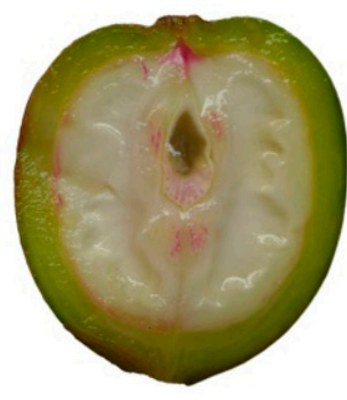

C

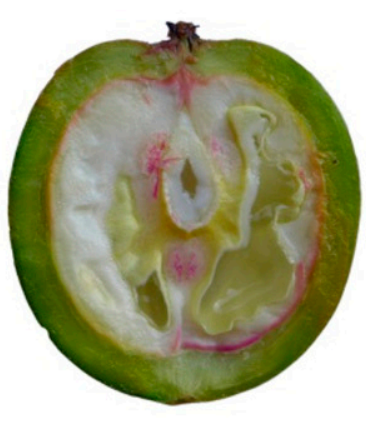

D

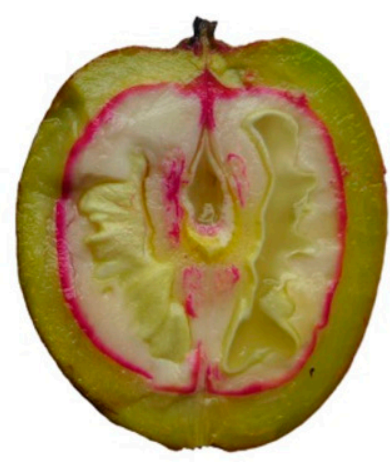

E

Fig. 2. Lignin deposition process in the walnut pericarp. The lignin is present mainly in endocarp sclereids as a red color based on the Wiesner reaction. No lignin was deposited at $35 \mathrm{~d}$ after flowering (DAF) (A). After $49 \mathrm{DAF}$, the endocarp showed gradual lignification from the apical tip to the base (B-D). After $70 \mathrm{DAF}$, the endocarp lignified from the outside to the inside $(\mathbf{E}-\mathbf{H})$. A significant increase in lignin deposition in the endocarp was observed before maturity.

strength of FH was greatest (337.57 Newton), and that of LH2 was the weakest $(63.56 \mathrm{~N})$. Nevertheless, the suture seal force of ZM $(211.80 \mathrm{~N})$ and QX $(201.17 \mathrm{~N})$ was significantly greater than the other cultivars, whereas that of LH1 $(69.29 \mathrm{~N})$, LH2 $(74.33 \mathrm{~N})$, and LB $(100.85 \mathrm{~N})$ was significantly weaker than the other cultivars. The data showed that suture seal force and mechanical strength of the thicker cultivars were typically greater than the thinner cultivars.

The shells were cryosectioned, and all the shells consisted of three parts as described earlier. TL1 accounted for the majority of the shell and constituted the thickest of the three layers in all cultivars. The L1 thickness of ZM was $1018.44 \mu \mathrm{m}$, which was the thickest of all cultivars, followed by that of FH $(993.77 \mu \mathrm{m})$, while that of LH2 $(599.31 \mu \mathrm{m})$ and LB $(612.67 \mu \mathrm{m})$ was thinner than the others. The ratio of $\mathrm{L} 2$ in the shell differed in all cultivars, and the L2 thickness of LH1 and LH2 was significantly thinner than the others. Similarly, the ratio of L 3 in the shell was different, and the L3 thickness of LH1 and LH2 was also thinner than the others, except for ZM $(29.53 \mu \mathrm{m})$.

Sclereid diameter in L1 was evaluated to assess the relationship between cell shape and the mechanical ability of the shell. The result showed that the shorter diameter of shell sclereids was associated with greater mechanical strength. For example, LH1 and LH2 were similar in thickness to L1, L2, and

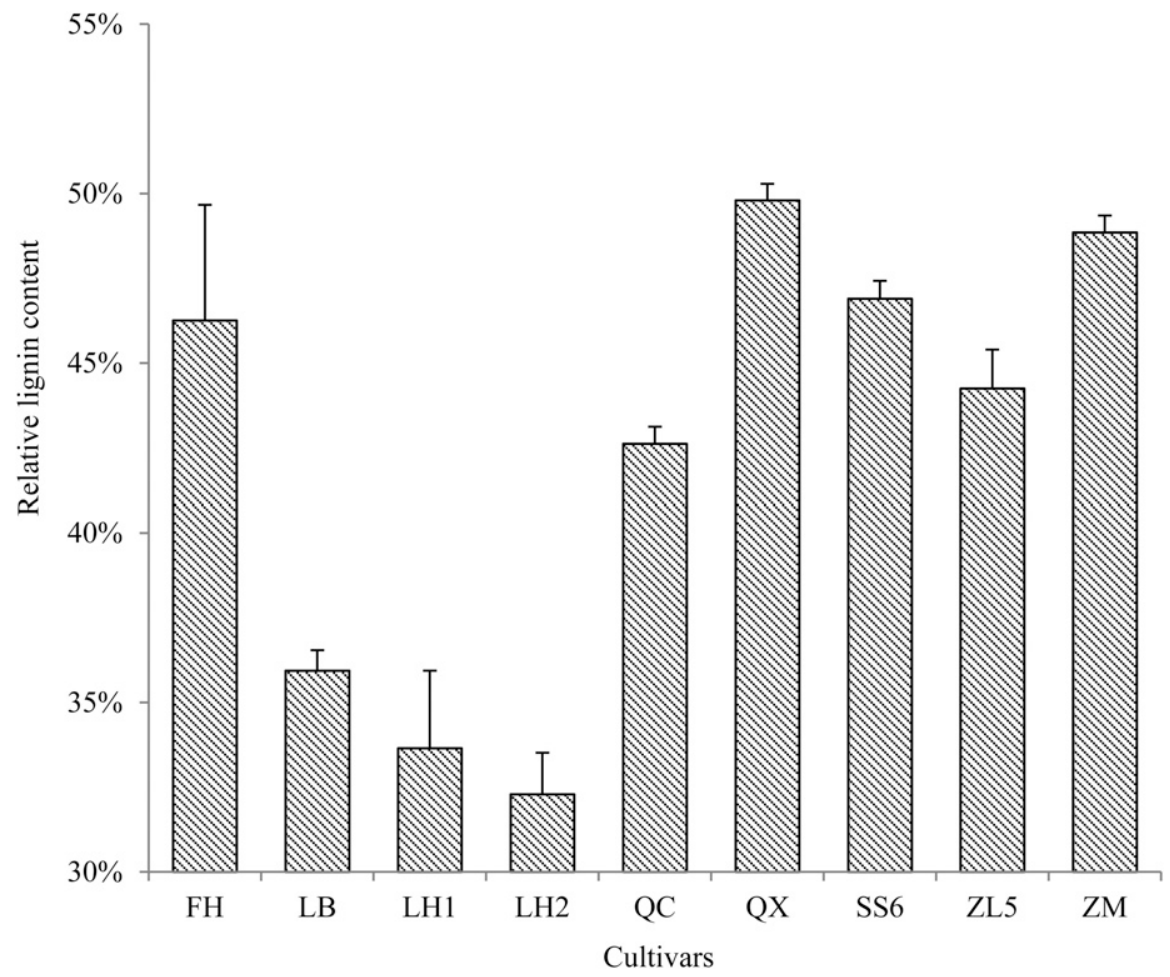

Fig. 3. Lignin content in the shells of nine walnut cultivars.

L3, but the diameter of their sclereids differed significantly, which led to the differences in their mechanical strength. The diameter of the LH2 sclereid was the longest of all cultivars. The other cultivars had comparable sclereid sizes. 
Lignin, cellulose, and polyphenol contents of the shell. Shell differentiation involves the transformation of the parenchymal cells of the endocarp into stone cells, which itself involves the process of secondary wall deposition of lignin. Thus, lignin content can reflect the degree of shell cell differentiation or the quantity of sclereids. The contents of lignin ranged from $30 \%$ to $50 \%$ (Fig. 3 ) in the mature shell of the different cultivars, and the shell lignin content of QC and ZM was higher than the others. The shell lignin content of LB, LH1, and LH2 was less than $40 \%$, which was significantly lower than the others, and these cultivars also had shell thicknesses of less than $0.9 \mathrm{~mm}$. Polyphenols are precursor substances of lignin synthesis and are closely associated with changes in lignin content. The polyphenol content ranged from $11.39 \mathrm{mg} / \mathrm{g}$ to $32.76 \mathrm{mg} / \mathrm{g}$ (Fig. 4). As observed with lignin content, the polyphenol content of QX was the highest $(32.76 \mathrm{mg} / \mathrm{g})$ and that of LH2 was the lowest (31.19 mg/g) of all the cultivars, which indicated the increasing tendency of cell lignification in the shell of QX.

Cellulose is an important structural component of cell walls, but the ratios of cellulose in the secondary cell walls and primary cell walls differ. Thus, cellulose content can reflect the lignification of the shell cells to some extent. The results showed that the cellulose content of ZL5 (11.2\%) was the lowest of all cultivars, followed by SS6, QC, and FH. ZM, LB, LH1, LH2, and QX possessed higher cellulose contents, all of which were greater than $15 \%$ (Fig. 5).

Correlation among shell structure, components, and physical properties. To investigate the relationship between shell components, structure, and their effect on physical properties, we calculated Pearson's correlation coefficients based on the compositional data (Figs. 3-5), structural data, and physical properties data (Table 1). Remarkable positive correlations were found between the shell structure, components, and physical properties (Table 2). Our analysis demonstrated that shell thickness was positively and significantly correlated with lignin content $\left(R^{2}=0.897\right)$, L1 thickness $\left(R^{2}=0.875\right)$, L2 thickness $\left(R^{2}=0.781\right)$, suture seal grade $\left(R^{2}=\right.$ $0.810)$, and mechanical strength $\left(R^{2}=0.747\right)$, but negatively and significantly correlated with shell cell diameter $\left(R^{2}=-0.692\right)$. This indicated that a thicker shell was correlated with a thicker L1 and L2, and the greater lignin content was associated with a stronger suture seal grade and mechanical strength, which were also associated with a smaller cell diameter. L1 thickness was also positively and significantly correlated with lignin content $\left(R^{2}=0.845\right)$, suture seal grade $\left(R^{2}=\right.$ $0.696)$, and mechanical strength $\left(R^{2}=0.763\right)$. Shell cell diameter was negatively and significantly correlated with shell thickness $\left(R^{2}=-0.692\right)$ and suture seal grade $\left(R^{2}=\right.$ $-0.711)$. Additionally, lignin content was significantly correlated with suture seal grade $\left(R^{2}=0.947\right)$ and mechanical strength $\left(R^{2}=\right.$ $0.830)$. In addition, suture seal grade was positively and significantly correlated with

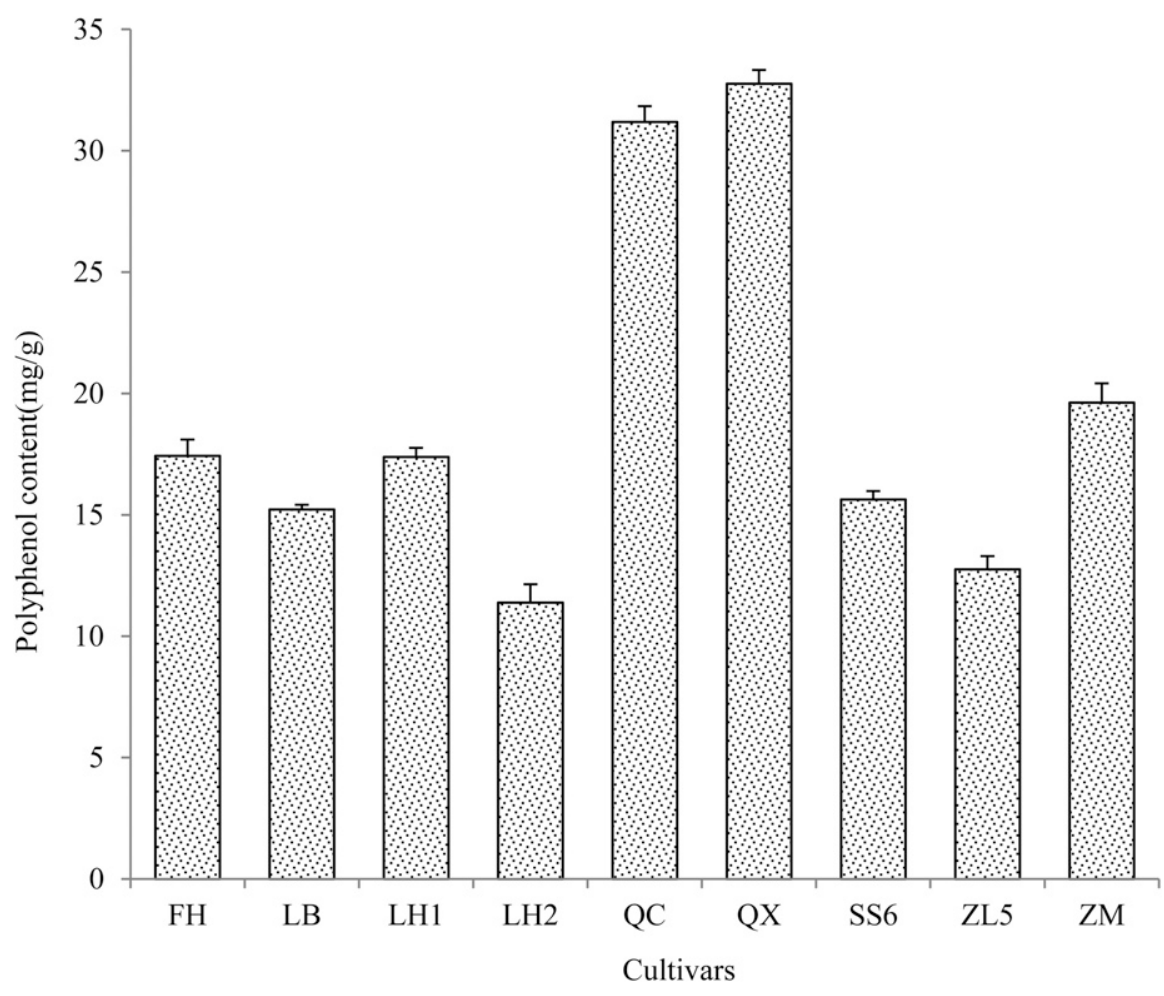

Fig. 4. Polyphenol content in the shells of nine walnut cultivars.

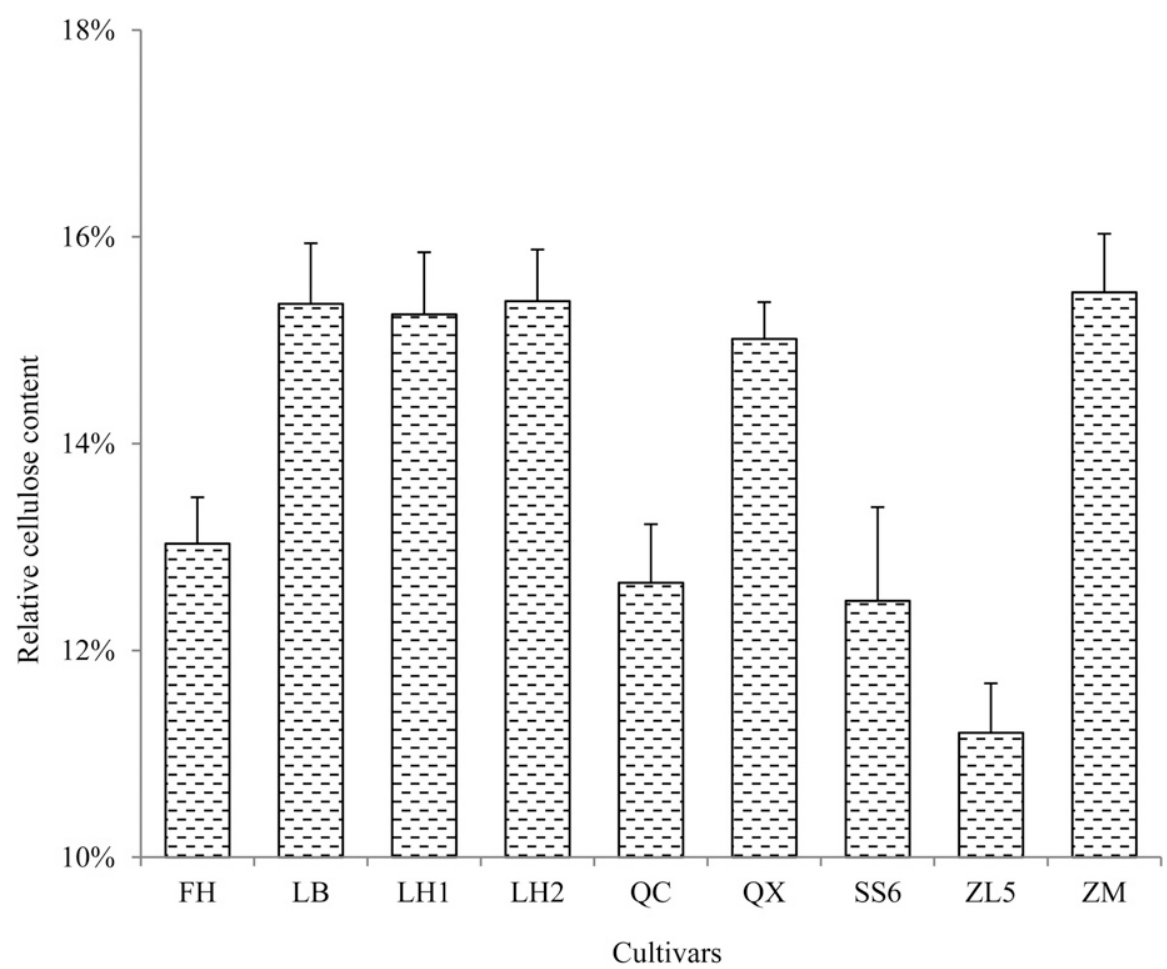

Fig. 5. Cellulose content in the shells of nine walnut cultivars.

mechanical strength. In summary, a thicker shell with a higher lignin content and smaller shell cells could result in a stronger suture seal grade and increased mechanical strength.

Different shading effects on walnut shells. The results showed that shading treatment significantly affected the structural composition and suture tightness (Table 3; the shell thickness of the $30 \%$ and $70 \%$ shading treatments was $0.93 \mathrm{~cm}$ and $0.89 \mathrm{~cm}$, respectively), which were significantly smaller than that of the control $(1.03 \mathrm{~cm})$. However, there were no significant differences between the $30 \%$ and $70 \%$ shading treatments. After shading, the thickness of the control was $864 \mu \mathrm{m}$, and that of the L1 and L2 layer 
Table 1. Structure, sclereid, and physical properties of walnut shell of nine cultivars.

\begin{tabular}{|c|c|c|c|c|c|c|c|}
\hline Cultivar & Shell thickness $(\mathrm{mm})$ & $\begin{array}{c}\text { Thickness of } \\
\mathrm{L} 1(\mu \mathrm{m})\end{array}$ & Thickness of L2 $(\mu \mathrm{m})$ & $\begin{array}{l}\text { Thickness of } \\
\text { L3 }(\mu \mathrm{m})\end{array}$ & $\begin{array}{c}\text { Sclereid } \\
\text { diam }(\mu \mathrm{m})\end{array}$ & $\begin{array}{l}\text { Mechanical } \\
\text { strength (N) }\end{array}$ & $\begin{array}{c}\text { Suture seal } \\
\text { force }(\mathrm{N})\end{array}$ \\
\hline LB & $0.89 \pm 0.15 \mathrm{c}$ & $613 \pm 47 \mathrm{e}$ & $180 \pm 19 b$ & $271 \pm 62 \mathrm{a}$ & $27 \pm 4 \mathrm{~cd}$ & $93.6 \pm 17.4 \mathrm{~d}$ & $100.9 \pm 17.3 \mathrm{~d}$ \\
\hline LH1 & $0.77 \pm 0.16 \mathrm{~d}$ & $642 \pm 88 \mathrm{e}$ & $39 \pm 9 \mathrm{e}$ & $27 \pm 6 \mathrm{~d}$ & $33 \pm 6 b$ & $114.7 \pm 48.3 \mathrm{~cd}$ & $69.3 \pm 21.4 \mathrm{e}$ \\
\hline QC & $0.93 \pm 0.11 \mathrm{c}$ & $629 \pm 116 \mathrm{e}$ & $116 \pm 17 \mathrm{c}$ & $184 \pm 62 b$ & $25 \pm 5 d$ & $195.1 \pm 21.3 \mathrm{~b}$ & $194.2 \pm 21.9 \mathrm{ab}$ \\
\hline QX & $1.03 \pm 0.13 \mathrm{~b}$ & $864 \pm 99 c$ & $83 \pm 14 \mathrm{~d}$ & $85 \pm 16 \mathrm{c}$ & $28 \pm 5 \mathrm{~cd}$ & $287.2 \pm 114.0 \mathrm{a}$ & $201.2 \pm 8.2 \mathrm{a}$ \\
\hline SS6 & $1.15 \pm 0.12 \mathrm{a}$ & $925 \pm 143 \mathrm{c}$ & $175 \pm 51 \mathrm{~b}$ & $63 \pm 18 \mathrm{c}$ & $27 \pm 3 \mathrm{~cd}$ & $276.6 \pm 276.6 \mathrm{a}$ & $172.4 \pm 47.4 \mathrm{bc}$ \\
\hline
\end{tabular}

Same column letters are Duncan's new multiple range test at the same level, and different letters represent significant differences at the $5 \%$ level.

$\mathrm{L} 1=$ sclereids layer; $\mathrm{L} 2$ = sclerenchymal cells layer; L3 = shrunken cell layer.

Table 2. Correlation coefficients for structure, sclereids, components, and physical properties of walnut shells.

\begin{tabular}{|c|c|c|c|c|c|c|c|c|c|c|}
\hline & $\begin{array}{c}\text { Shell } \\
\text { thickness }\end{array}$ & L1 thickness & L2 thickness & L3 thickness & Shell cell diam & $\begin{array}{l}\text { Lignin } \\
\text { content }\end{array}$ & $\begin{array}{c}\text { Polyphenol } \\
\text { content }\end{array}$ & $\begin{array}{c}\text { Cellulose } \\
\text { content }\end{array}$ & $\begin{array}{l}\text { Suture seal } \\
\text { grade }\end{array}$ & $\begin{array}{l}\text { Mechanical } \\
\text { strength }\end{array}$ \\
\hline L1 thickness & & 1 & 0.466 & -0.465 & -0.386 & $0.845^{* *}$ & 0.093 & -0.176 & $0.696^{*}$ & $0.763 *$ \\
\hline L2 thickness & & & 1 & 0.444 & -0.662 & 0.517 & -0.220 & -0.553 & 0.489 & 0.365 \\
\hline Shell cell diameter & & & & & 1 & -0.660 & -0.481 & 0.370 & $-0.711^{*}$ & -0.486 \\
\hline Lignin content & & & & & & 1 & 0.471 & -0.376 & $0.947 * *$ & $0.830 * *$ \\
\hline Polyphenol content & & & & & & & 1 & 0.050 & 0.595 & 0.413 \\
\hline Mechanical strength & & & & & & & & & & 1 \\
\hline
\end{tabular}

$*, * *$ Correlations were considered significant at the 0.05 and 0.01 levels, respectively.

$\mathrm{L} 1=$ sclereids layer; $\mathrm{L} 2=$ sclerenchymal cells layer; L3 $=$ shrunken cell layer.

Table 3. Structure, sclereid, physical properties, and content of walnut shells after different shading treatments.

\begin{tabular}{|c|c|c|c|c|c|c|c|c|c|}
\hline & $\begin{array}{c}\text { Shell } \\
\text { thickness (mm) }\end{array}$ & $\begin{array}{l}\text { L1 thickness } \\
\qquad(\mu \mathrm{m})\end{array}$ & $\begin{array}{l}\text { L2 thickness } \\
\qquad(\mu \mathrm{m})\end{array}$ & $\begin{array}{l}\text { L3 thickness } \\
\qquad(\mu \mathrm{m})\end{array}$ & $\begin{array}{c}\text { Sclereid } \\
\text { diam }\end{array}$ & $\begin{array}{c}\text { Lignin } \\
\text { content (\%) }\end{array}$ & $\begin{array}{c}\text { Polyphenol } \\
\text { content (mg/g) }\end{array}$ & $\begin{array}{l}\text { Cellulose } \\
\text { content }(\%)\end{array}$ & Suture seal grade $(\mathrm{N})$ \\
\hline $30 \%$ Shading & $0.93 \pm 0.15 b$ & $775 \pm 13 b$ & $71 \pm 13 b$ & $87 \pm 8 b$ & $29 \pm 5 \mathrm{a}$ & $48.4 \pm 0.0 \mathrm{~b}$ & $19.8 \pm 0.3 b$ & $15.2 \pm 0.0 \mathrm{a}$ & $191.38 \pm 38.0 \mathrm{a}$ \\
\hline
\end{tabular}

Same column letters are Duncan's new multiple range test at the same level, and different letters represent significant differences at the $5 \%$ level.

$\mathrm{L} 1=$ sclereids layer; L2 = sclerenchymal cells layer; L3 = shrunken cell layer.

decreased by $30 \%$ and $70 \%$, respectively, and the cell layer thickness of the walnut hardstone was $775 \mu \mathrm{m}$ and $594 \mu \mathrm{m}$, respectively. The thickness of the thick-walled cell layer was $83 \mu \mathrm{m}, 71 \mu \mathrm{m}$, and $59 \mu \mathrm{m}$, respectively. However, shading increased the thickness of the fibrosis layer, and the $70 \%$ shading treatment differed significantly from the control. The content of lignin in the hard shell treated with $30 \%$ and $70 \%$ shading was $48.37 \%$ and $47.84 \%$, respectively, which was significantly lower than that of the control (49\%). The content of polyphenols was similar to that of the control, but the content of cellulose was unaffected by shading. In addition, shading did not affect cell size. It is evident that shading inhibits the formation of the stone cell layer and changes the proportion of the three types of tissue layers in the hard shell structure, which is detrimental to the supporting function of the hard shell. The suture tightness of the $70 \%$ shaded walnut was $121.33 \mathrm{~N}$, which was significantly lower than that of the control $(201.2 \mathrm{~N})$.

\section{Discussion}

Sclereids, typified by thick secondary walls, exist in the shells of nuts, bark, pith, leaves, and sarcocarps of pear fruit, and in the secondary xylem of certain taxa (Fahn, 1967; Lee et al., 2006). Previous studies have indicated that walnut shell is composed of sclereids (Zhao et al., 2007, 2016), which are differentiated from the parenchymal cells in the endocarp (Xiao et al., 1998). Zhang et al. (2014a, 2014b) assessed walnut shells using scanning electron microscopy, and the results showed that the shell consisted of two layers according to the different patterns of cell fracture. In the present study, the development of the walnut endocarp was scrutinized. Our findings showed that the mature shell consisted of sclerenchyma not only in the sclereids but also in some cells with partly thickened secondary walls and shrunken cells. Shell differentiation started from the outside of the endocarp and sclereids and progressed gradually. As fruit ripening proceeded, the endocarp cells lignified and gradually stopped differentiating. Ultimately, the cells that completely turned into sclereids were those in the outermost stratum of the endocarp, called stone cell layers. The mesial cells of the endocarp covered by the stone cell layer stopped differentiating during the process of secondary wall thickening and became special sclerenchyma cells with partly thickened secondary walls. The inner cells near the embryo, which maintained parenchymal cells during the entire process, ultimately desiccated and shrunk into dead tissue.

Currently, sclereids are thought to be formed through a mass of lignin, cellulose, and other components deposited on the parenchymal cells, and are elementary units of nonwoody structures (Tao et al., 2009). The lignification of the peach endocarp, also composed of sclereids that function in mechanical support, begins at $40 \mathrm{~d}$ after full bloom and is completed 15 d later (Abeles and Biles, 1991; Yang et al., 2009). In contrast, the lignification process of the endocarp indicated that the shell was formed gradually from the outside until fruit maturation and was accompanied by lignin sedimentation, as verified by the Wiesner reaction. In contrast, the shell consisted of three portions as described earlier in the article, in which the thickest layer was the outermost one with highly thickened, lignified sclereids. More lignin is expected to be located at the stone cell layer of the shell, less lignin should be located at the L2 layer, and no lignin should be present on the L3 layer, which was verified by the correlation analysis. The thicker the sclereid layer, the greater the lignin content was.

Thin shells have been the primary character focus of farmers in recent years as a result of Chinese consumer preference for thin-shelled cultivars. Due to the popularity 
and wide cultivation of thin-shelled walnuts in China, most cultivars experience serious weaknesses associated with worm and phytopathogen infection, as well as a poor appearance owing to the fragile shell and loose suture seal grade (Lu et al., 2010; Ma et al., 2011). Zhao et al. (2007) found that shell structure and nutmeat quality were directly correlated, with a hard shell being associated with good sealability, owing to the light kernel color, better storability, and a lower ratio of contamination and infestation. Arzani et al. (2008) indicated that shell thickness was significantly positively correlated with nut weight. Xavier (1992) emphasized that size, shape, shell thickness, and texture were the most important parameters affecting the kernel extraction quality in macadamia nut. These findings suggest that the shell structure, including the seal grade, thickness, and mechanical strength, should be considered when evaluating walnut quality. Here, some correlations between these structural indices, lignin content, and shell thickness were observed. In particular, the L1 layer was positively correlated with the suture seal grade and mechanical strength, while the shell cell diameter exhibited the opposite pattern. Lignin, a phenylpropanoidderived polymer, is naturally present in the specific cell types of vascular plants, particularly those with secondarily thickened cell walls that function in mechanical support and pathogen defense (Zhao and Dixon, 2011; Zhao et al., 2013). Thus, the high content of lignin should be the major factor leading to stronger shell mechanical strength and seal grade. Remarkably, the L1 layer consists of sclereids, which constitute the main point of lignin deposition in the shell. Conversely, lignin deposition, a key mechanism in host resistance, contributes to cell wall lignification, which may retard pathogen colonization (Alwis et al., 2009; Hahlbrock and Scheel, 2003). The lignin content of the QX walnut shell was significantly higher than the other cultivars, which could explain its popularity and high resistance to disease. Further clarification of the role of lignin in shell development and disease resistance in walnut is warranted.

Finally, shell development is closely related to light intensity. Zhao et al. (2011) reported significant differences in shell density and thickness within the same cultivar when produced in a different region. There was also a significant negative correlation between the proportion of poor-development shell nut and the light intensity (Cui and Guo, 2008). It was found that the same cultivar performed well in Xinjiang Province with sufficient light, but it often showed poordevelopment shell nuts with partial naked kernels in other areas with insufficient light (Zhao et al., 2011), which agrees with the results of our shading treatment. Therefore, we suggest that rational planting density and good illumination is necessary for producing highquality nuts.

\section{Conclusion}

The shell consists of three parts, including the stone cell layer, sclerenchymal cell layer, and shrunken cell layer. The differentiation of the shell begins on the outside of the endocarp and continues until fruit maturation. The thickness of the shell was significantly correlated with seal grade and mechanical strength, and lignin was determined to be the major factor affecting the shell structure.

\section{Literature Cited}

Abeles, F.B. and C.L. Biles. 1991. Characterization of peroxidases in lignifying peach fruit endocarp. Plant Physiol. 95:269-273.

Abidi, N., L. Cabrales, and C.H. Haigler. 2014 Changes in the cell wall and cellulose content of developing cotton fibers investigated by FTIR spectroscopy. Carbohydr. Polym. 100:9-16.

Alwis, R.D., K. Fujita, T. Ashitani, and K.I. Kuroda. 2009. Induced monoterpene and lignin production in mechanically stressed and fungal elicited cultured Cupressus lusitanica cells. Plant Biotechnol. Rpt. 3:57-65.

Amiri, R., K. Vahdati, S. Mohsenipoor, R.M. Mohammad, and C. Leslie. 2010. Correlations between some horticultural traits in walnut. HortScience 45:1690-1694.

Arzani, K., H. Mansouri-Ardakan, A. Vezvaei, and M.R. Roozban. 2008. Morphological variation among persian walnut (Juglans regia) genotypes from central Iran. N. Z. J. Crop Hort. Sci. 36:159-168.

Avanzato, D., G.H. McGranahan, K. Vahdati, M. Botu, L. Iannamico, and J. Van Assche. 2014 Following walnut footprints (Juglans regia L.) cultivation and culture, folklore and history, traditions and uses. International Society for Horticultural Science, Leuven, Belgium.

Cui, H.Y. and S.P. Guo. 2008. Research on impact of some factors on poor development of thinskinned nuts. Hebei Fruits 3:7-8.

Ding, D., Y. Zhao, S. Yang, W. Shi, Z. Zhang, Z. Lei, and Y. Yang. 2013. Adsorption of cesium from aqueous solution using agricultural residue-walnut shell: Equilibrium, kinetic and thermodynamic modeling studies. Water Res. 47:2563-2571.

Fahn, A. 1967. Plant anatomy. Pergamon Press Ltd., Oxford, UK

Ghafari, A., G.R. Chegini, J. Khazaei, and K. Vahdati. 2011. Design, construction and performance evaluation of the walnut cracking machine. Intl. J. Nuts Related Sci. 2:11-16.

Hahlbrock, K. and D. Scheel. 2003. Physiology and molecular biology of phenylpropanoid metabolism. Annu. Rev. Plant Biol. 40:347-369.

Khantwal, R., G. Gupta, and R.S. Negi. 2016. Walnut shell reinforced composite: A Review. Intl. J. Sci. Eng. Res. 7:179-189.

Lee, S.H., J.H. Choi, W.S. Kim, T.H. Han, Y.S. Park, and H. Gemma. 2006. Effect of soil water stress on the development of stone cells in pear (Pyrus pyrifolia cv.'Niitaka') flesh. Scientia Hort. 110:247-253.

Lin, J., X. He, Y. Hu, T. Kuang, and R. Ceulemans. 2002. Lignification and lignin heterogeneity for various age classes of bamboo (Phyllostachys pubescens) stems. Physiol. Plant. 114:296-302.

Lu, M., Q. Zhang, and J. Yang. 2010. Research on preservation and year-round supply technique of fresh-eating walnut. Shandong Agr. Sciences 3:81-83.

Ma, Y., H. Ma, X. Liu, and S. Li. 2011. Comparison of physiology and nutrition in dry and fresh walnut during the storage. Food and Fermentation Ind. 37:235-238.

Pei, D. and X.Z. Lu. 2011. Walnut germplasm resources in China. China Forestry Press, Beijing, China.

Pinney, K. and V.S. Polito. 1983. English walnut fruit growth and development. Scientia Hort. 21:19-28.

Tao, S., S. Khanizadeh, H. Zhang, and S. Zhang. 2009. Anatomy, ultrastructure and lignin distribution of stone cells in two Pyrus species. Plant Sci. 176:413-419.

Taylorteeples, M., L. Lin, M. De Lucas, G. Turco, T. Toal, A. Gaudinier, N.F. Young, G.M. Trabucco, M.T. Veling, and R. Lamothe. 2014. An Arabidopsis gene regulatory network for secondary cell wall synthesis. Nature 517:571-575.

Updegraff, D.M. 1969. Semimicro determination of cellulose in biological materials. Anal. Biochem. 32:420-424.

Xavier, J.A. 1992. Study of macadamia nut breakage. Unpublished M.Sc. Thesis, Botucatu, SP, UNESP.

Xi, S.K. 1990. Walnut improvement in China. Acta Hort. 284:195-197.

Xiao, L., Y. Xu, X. Zhao, and J. Luo. 1998. The developmental anatomy on the pericarp of Juglans regia. Acta Botanica Boreali-Occidentalia Sinica 18:577-580.

Yang, A.Z., Z.Y. Zhang, A.J. Cao, H.L. Meng, and Y.N. Wang. 2009. Studies of changes in sugar accumulation and lignin deposition during peach fruit endocarp development. Acta Hort. Sinica 36:1113-1119.

Yuan, H.R. and R.H. Liu. 2007. Study on pyrolysis kinetics of walnut shell. J. Therm. Anal. Calorim. 89:983-986.

Zhang, H., H. Lan, Y. Tang, and Y. Li. 2014a. Study on fracture mechanism of walnut shell according to brittle fracture area, p. 954-957. In: J.E. Guerrero (ed.). Fifth International Conference on Intelligent Systems Design and Engineering Applications, Conference Publishing Services, Danvers, MA.

Zhang, H., Y. Ma, W. Guo, R. Zhang, and Y. Li 2014b. Analysis on the embrittlement mechanism of Wen-185 walnut shell based on the cellular tissue. J. Huazhong Agr. Univ. 33:128-132.

Zhao, Q. and R.A. Dixon. 2011. Transcriptional networks for lignin biosynthesis: More complex than we thought? Trends Plant Sci. $16: 227-233$.

Zhao, Q., J. Nakashima, F. Chen, Y. Yin, C. Fu, J. Yun, H. Shao, X. Wang, Z.Y. Wang, and R.A. Dixon. 2013. Laccase is necessary and nonredundant with peroxidase for lignin polymerization during vascular development in Arabidopsis. Plant Cell 25:3976-3987.

Zhao, S., Y. Zhao, H. Wang, Y. Gao, Z. Zhang, and D. Feng. 2011. Factors affecting nutshell structure of walnut. Scientia Silvae Sinicae 47:70-75.

Zhao, S., J. Wen, H. Wang, Z. Zhang, and X. Li. 2016. Changes in lignin content and activity of related enzymes in the endocarp during the walnut shell development period. Hort. Plant J. 2:141-146.

Zhao, Y., S. Zhao, H. Wang, Z. Zhang, and Y. Gao. 2007. The relations between shell structures and kernel qualities of Juglans regia. Scientia Silvae Sinicae 43:81-85. 